\title{
The Determination of Nitric Oxide in Gas Phase Cigarette Smoke by Non-dispersive Infrared Analysis*
}

\author{
by T.B. Williams \\ Research Department, Liggett \& Myers Tobacco Co., Inc., \\ Durbam, North Carolina, U.S.A.
}

\section{INTRODUCTION}

Prior to 1973 , nitrogen oxides $\left(\mathrm{NO}_{\mathrm{x}}\right)$ in cigarette smoke were almost universally determined by the Saltzman procedure or a modification thereof $(1-4)$. A few procedures involved other color forming reagents $(5-7)$ but almost all required nitric oxide (NO) oxidation to nitrogen dioxide $\left(\mathrm{NO}_{2}\right)$ and absorption in solution before measurement. These procedures were time-consuming and, usually, only one cigarette was smoked per analysis.

In 1969, an ultraviolet spectrophotometric determination of NO in fresh smoke was presented (8) at the 23rd Tobacco Chemists' Research Conference (TCRC) and in 1973 a non-dispersive infrared (NDIR) determination was presented (9) at the 27 th TCRC. Since then, the chemiluminescence technique has been applied to cigarette smoke analysis $(10-12)$. These rapid instrumental methods can be adapted to multi-port smoking machines to yield an average delivery of several cigarettes.

The NDIR analyzers are used extensively in carbon monoxide $(\mathrm{CO})$ and carbon dioxide $\left(\mathrm{CO}_{2}\right)$ analyses but can be applied to NO analysis as well. In fact these gases can be determined simultaneously in a puff-by-puff analysis of the same cigarettes, employing three analyzers in series or in parallel combinations.

Of the nitrogen oxides, only NO is measured by NDIR. It is widely accepted that $\mathrm{NO}_{2}$ is present in very low concentrations in fresh smoke $(3,12,13)$ but increases with time due to oxidation of NO. Therefore, an analysis should be performed as soon as possible after a puff is taken. By the NDIR method, the NO is determined within 15 seconds of the puff.

The NO, $\mathrm{CO}$ and $\mathrm{CO}_{2}$ deliveries of a sample can be obtained in duplicate within 30 minutes after the first set is lit and as many as $8-10$ samples can be analyzed in a day with one unit, depending on the replication desired. In contrast, most wet analyses require at least an hour for complete oxidation of $\mathrm{NO}$ to $\mathrm{NO}_{2}$. In some instances, the coloring agents will decompose during this time to yield erroneous values.

For comparison purposes, a wet analysis (14) and an NDIR analysis of NO were extensively investigated, and factors affecting both analyses were examined.

\footnotetext{
* Reccived: 10th April 1979 - accepted: 27th September 1979.
}

\section{EXPERIMENTAL}

\section{Smoking Machine}

The delivery and analyses depend on the type of machine generating the smoke. The shape of the puff profile, the control of drafts, and the fraction of the puff analyzed are especially important. Cigarettes with highly perforated filters, smoked on a machine (15) utilizing critical flow orifices (CFO) yielded lower CO deliveries than the widely used 20-port Philip Morris syringe-type smoking machine (16). Both smoking machines yielded representative samples and the draft was controlled so the influence of the puff profile was suspected. The CFO machine took two thirds of a puff in the first second of a two-second puff compared to one-half puff per second taken by the syringe machine. To eliminate this difference, the small eight-port machine pictured in Figures 1 and 2 was constructed which produced puff profiles, $\mathrm{CO}$ and nicotine deliveries in agreement with the 20 -port syringe smoking machine. A more sophisticated unit, the Filtrona Model 302 with fractional puff cut-offs, could have been purchased, but syringes, swivels and drive were available and the assembly required little labor and expense.

The syringe drive (Filamatic DAB-8 H.T.), syringes $(50 \mathrm{ml})$, swivels, etc. were purchased from the National Instrument Company, Inc. of Baltimore, Maryland. These were adapted to a suitable frame and shafts essentially patterned after the Philip Morris machine, including outboard chain drives. The three-way solenoid valves (Skinner Precision Industries Inc., New Britain, Connecticut) were actuated by a microswitch operated by a cam on the syringe drive. To reduce dead volume, they were attached to the top syringe swivels by one-eighth inch polyethylene tubing and the Cambridge filter cassettes were held in the valve heads by " $O$ " rings. The syringes' swivels were spring loaded at the top to reduce breakage in case of sticking since the syringe swivels contained no lubricant that might absorb or react with nitrogen oxides. They were adjusted to $35 \mathrm{ml}$ volume by the crank arm and individually by the bottom barrel holder and top spring adjustments. The exhaust of the syringes passed through one-fourth inch polyethylene tubing of about $20 \mathrm{ml}$ dead volume to a polyethylene bag for mixing (17). The filling and exhausting of the bag required 15 seconds or less for $280 \mathrm{ml}$ $(8-35 \mathrm{ml}$ puffs $)$ and was controlled by a solenoid valve 
Figure 1. Eight-port smoking machine.

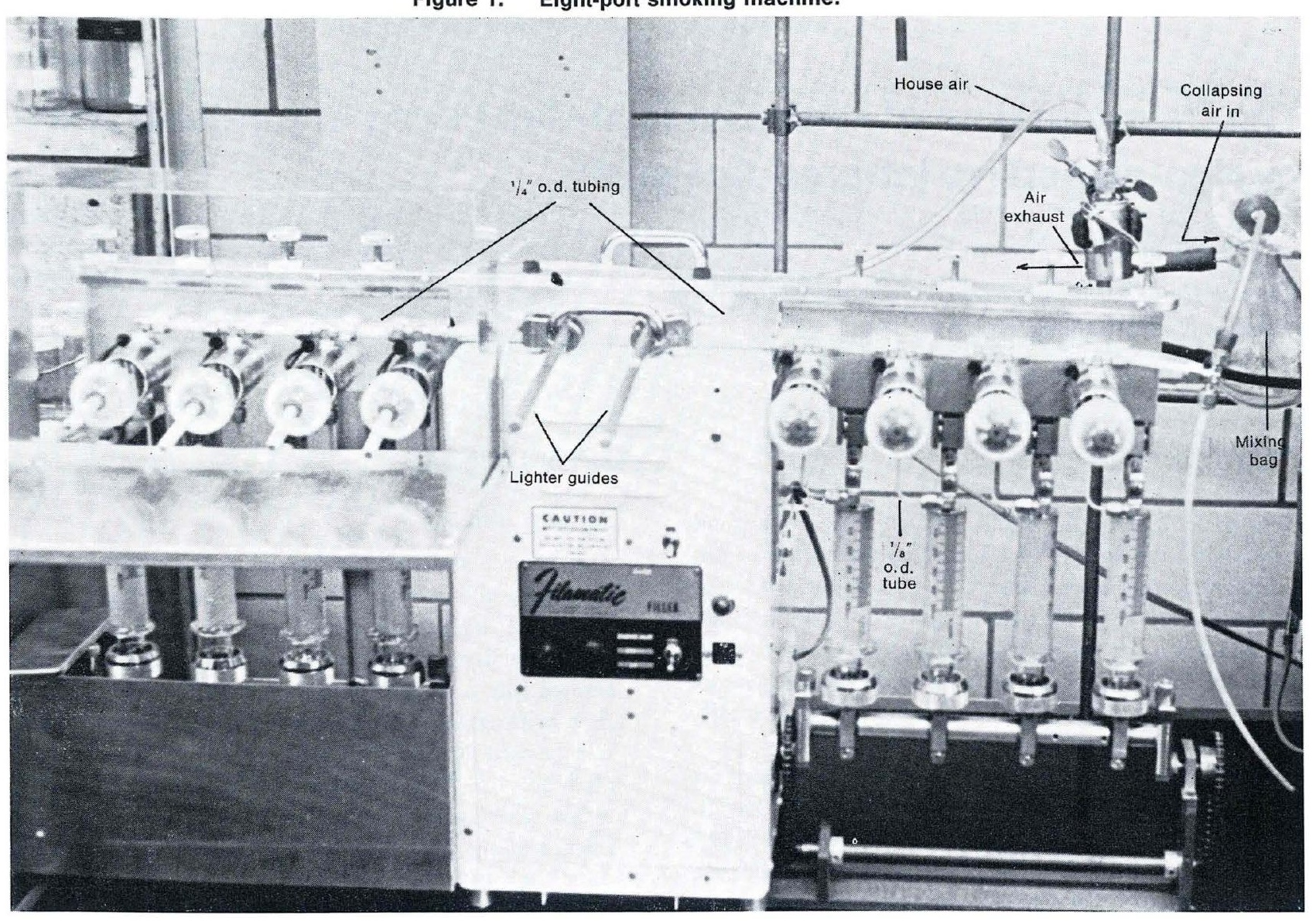

Figure 2. Smoking machine and non-dispersive infrared (NDIR) analyzers.




synchronized with the eight-port solenoids. The valve released air surrounding the bag when the puff was exhausted from the syringes and admitted pressurized air around the bag to expel the gas phase to the analyzers. The bag was collapsed except during the time it accepted and expelled the exhaust from the smoking machine so dilution was negligible. In a $280 \mathrm{ml}$ puff only $20 \mathrm{ml}$ of dead volume was contributed by the machine lines compared to $72 \mathrm{ml}$ contributed by the eight Cambridge filter cassettes.

Since the laboratory ventilation created air currents, a draft fence and shelf around and below the cassettes prevented an updraft. The draft past the cigarettes was $15-20$ lineal feet per minute with this baffling. Excessive draft increased diffusion out of the cigarette during a puff, increased static burn rate, and decreased puff number. Baker and Crellin (18) have discussed this effect in some detail.

\section{Non-dispersive Infrared (NDIR) Analyzers}

The exhaust from the syringes and the bag passed through a Beckman NDIR 215A CO analyzer, a Beckman $865 \mathrm{CO}_{2}$ analyzer, through a silica gel capsule, a $\mathrm{LiCl}$ capsule and through the Beckman 215A NO analyzer. All three analyzers operated on the same principle as described in Beckman NDIR manuals or as discussed by Siggia (19). The path lengths of the $\mathrm{CO}$ and $\mathrm{CO}_{2}$ cells were about onefourth inch but the NO cell was 13.5 inches long to obtain sufficient absorption at the low NO concentrations. This long cell allowed the NO analyzer to be normally operated at only $25 \%$ gain. For higher nitrate samples, the gain was reduced and it was raised for low-yield samples. Two additional ranges allowed a two- and a four-fold increase in sensitivity at any gain setting for analysis of extremely low NO levels. The cell volume, about $100 \mathrm{ml}$, was swept out twice by the $280 \mathrm{ml}$ exhaust from the smoking machine, insuring no dilution by the previous sample. The silica gel capsule removed interferences, especially aldehydes, and the $\mathrm{LiCl}$ capsule aided in water removal, all of which responded as NO. The analyzers were zeroed on air puffs from the smoking machine and gain was set with standard gases admitted through the line following the mixing bag. Both zeroing air and standards passed through the capsules. Fresh silica gel capsules $(6 \mathrm{~mm}$ inside diameter $\times 12 \mathrm{~cm}$ ) were inserted before each set of cigarettes was smoked.

Daily calibrations were determined at least once with two $\mathrm{CO}-\mathrm{CO}_{2}$-air standards and two $\mathrm{NO}-\mathrm{N}_{2}$ standards (Air Products, Tamaqua, Pa.). At approximately two-month intervals, complete calibration curves were obtained by diluting standards and/or pure gases. The puff by puff cigarette deliveries were calculated by a Hewlett-Packard $9100 \mathrm{~B}$ program based on these $\mathrm{CO}, \mathrm{CO}_{2}$ and $\mathrm{NO}$ calibrations (17) and the constants were re-evaluated if calibrations changed.

\section{Nitric Oxide Recovery}

The CO deliveries by this system were corroborated to within a few percent by the $\mathrm{CO}$ delivered by the 20 -port
Philip Morris machine located in a hood with $15-20$ lineal feet per minute controlled draft. The NO recovery was examined as follows. A 2030 or $1050 \mathrm{ppm} \mathrm{NO}$ in $\mathrm{N}_{2}$ standard was taken through $\mathrm{x}$ ports along with air taken through $(8-x)$ ports of the smoking machine. These puffs were mixed in the bag and passed through the NDIR analyzer for measurement of recovery. Similarly, one port of $2030 \mathrm{ppm} \mathrm{NO}$ in $\mathrm{N}_{2}$ standard was taken through one port of the smoking machine while cigarettes were smoked in the other seven ports. This was repeated taking air through one port with seven cigarettes and also taking NO through one port and air through seven ports. Comparison of NO levels at these three conditions allowed estimation of NO recovery from cigarette smoke.

\section{Analysis of Cigarettes}

Cigarettes were equilibrated at $74 .{ }^{\circ} \mathrm{F}$ and $60 \%$ relative humidity for at least 48 hours and were kept in plastic bags until placed in the cassettes. They were lit simultaneously with an eight-port electric lighter and smoked to tipping plus three $\mathrm{mm}$ or to a $23 \mathrm{~mm}$ butt in case of non-filter cigarettes. Since this apparatus was not equipped with fractional puff cut-offs, a cigarette was removed from a cassette if the next puff would burn through the prescribed butt length. The fractional puff was then $x / 8$ where $\mathrm{x}$ was the number of cigarettes that were long enough for the last puff. Air was drawn through the empty ports when the fractional puff was taken and clearing puffs were taken on empty ports after the last puff. These could be taken manually so that residual NO did not remain in the system for 58 seconds between clearings. The NO, $\mathrm{CO}$, and $\mathrm{CO}_{2}$ meter readings were recorded after each puff and $\mathrm{ml}$ or $\mathrm{mg}$ delivered were calculated by the HP9100B programmed calculator.

\section{RESULTS AND DISCUSSION}

\section{Non-dispersive Infrared (NDIR) Analyses}

The recovery of NO from various NO-air mixtures after the 15 -second period for the mixing bag to exhaust and for the NDIR to stabilize is shown in Figure 3. The average recovery at the various air ratios was $95 \%$ of that expected had only dilution of the standard occurred. The recovery of $\mathrm{NO}$ added to cigarette smoke under conditions similar to the above is shown in Figure 4. In the presence of high levels of smoke, recovery averaged only $87 \%$ while at lower levels, recovery averaged $91 \%$. In smoke, the added NO could react with other smoke components such as amines, alcohols, etc. to form nitrosamines, methyl nitrite, etc. (20), accounting for the lower recoveries. Also, these reactive components would be at lower levels in smoke from a dilution filter cigarette so the higher recovery above would be expected.

The reproducibility of deliveries by a prototype cavity filter cigarette is shown in Table 1 . The variations over a period of three months are shown for a controlled draft 
Figure 3. Recovery of nitric oxide from nitric oxide - alr mixtures through the smoking machine.

$O$ : average of 12 puffe at each ratlo

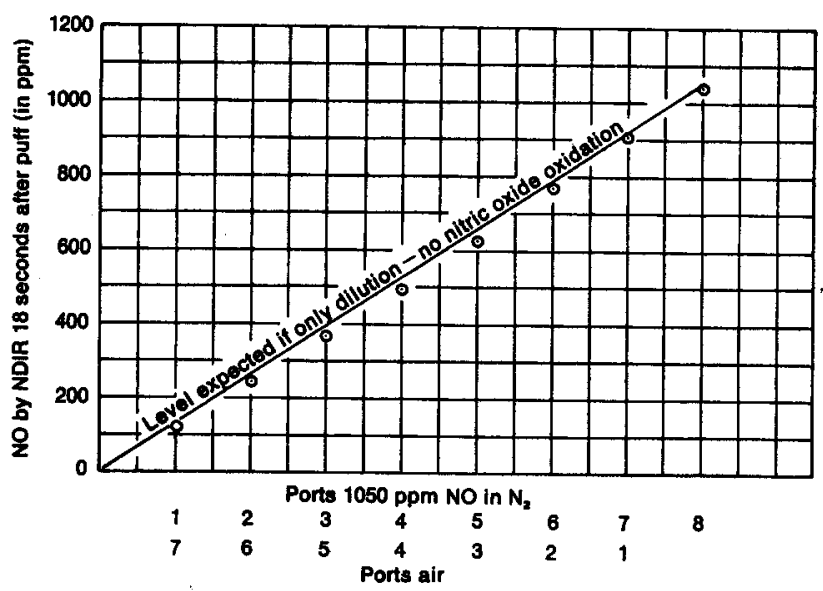

Figure 4. Recovery of nitric oxide added to smoke from hlgh-yleld and low-yleld clgarettes.

average of 6 determinations $0: 1$ port NO +7 cigarettes ㅁ: 1 port air +7 cigarettes $\Delta: 1$ port NO +7 ports air

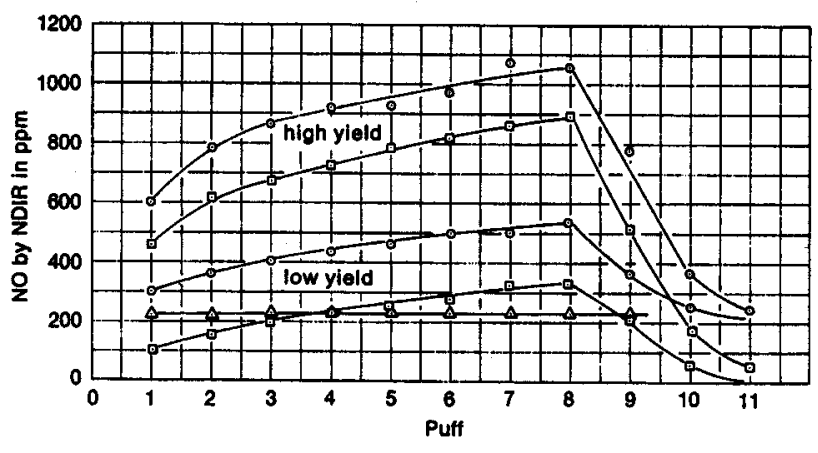

Table 1. Reproducibility of dellveries of the same cigarette over oxtended periods.

\begin{tabular}{|c|c|c|c|c|}
\hline Day & $\mu g$ NO/cigarette & mg CO/cigarette & $\mathrm{mg} \mathrm{CO} /$ cigarette & Puffs \\
\hline & \multicolumn{4}{|c|}{ Draft controlled } \\
\hline 1 & 331, 331 & $17.3,17.1$ & $56.7,55.8$ & $7.9,7.9$ \\
\hline 2 & 331,356 & $16.4,17.5$ & $56.2,58.1$ & $8.1,7.9$ \\
\hline 3 & 347,348 & $17.7,16.9$ & $58.3,58.7$ & $7.9,7.9$ \\
\hline 10 & 331 & 16.5 & 54.9 & 7.9 \\
\hline 47 & 365,336 & $18.1,16.5$ & $59.6,58.0$ & $8.2,8.2$ \\
\hline 100 & 314,319 & $15.8,15.3$ & $56.2,55.8$ & $7.4,7.4$ \\
\hline \multirow[t]{2}{*}{$\begin{array}{l}\text { Mean } \pm \text { standard deviation } \\
\text { Coefficient of variation }\end{array}$} & $\begin{array}{l}336 \pm 13 \\
4.0 \%\end{array}$ & $\begin{array}{l}16.8 \pm 0.8 \\
4.9 \%\end{array}$ & $\begin{array}{l}57.2 \pm 1.7 \\
3.0 \%\end{array}$ & \\
\hline & \multicolumn{4}{|c|}{ Draft uncontrolled } \\
\hline $\begin{array}{l}\text { Mean } \pm \text { standard deviation } \\
\text { Coefficient of variation }\end{array}$ & $\begin{array}{l}304 \pm 9 \\
2.8 \%\end{array}$ & $\begin{array}{l}15.5 \pm 0.6 \\
4 \%\end{array}$ & $\begin{array}{l}52.2 \pm 1.8 \\
3.4 \%\end{array}$ & $\begin{array}{l}7.2-8.5 \\
(n=13)\end{array}$ \\
\hline
\end{tabular}

Table 2. Velocity constants for nitric oxide oxidatlon measured by non-dlepersive Infrared spectroscopy (NDIR).

\begin{tabular}{c|c|c|c|c}
\hline Ports NO (x) & $\begin{array}{c}\text { NO } \\
(\mathrm{mol} / \mathrm{l})\end{array}$ & $\begin{array}{c}\mathrm{O}_{2} \\
(\mathrm{~mol} / \mathrm{l})\end{array}$ & $\begin{array}{c}\text { Loss } \\
(\%)\end{array}$ & $\begin{array}{c}\mathrm{k} \\
\left(\mathrm{I}^{2} \mathrm{~mol}^{-2} \mathrm{~min}^{-1}\right)\end{array}$ \\
\hline Ports air $(8-x)$ & $5.46 \cdot 10^{-0}$ & $7.66 \cdot 10^{-3}$ & 4.0 & $3.3 \cdot 10^{\circ}$ \\
$\frac{1}{7}$ & 10.93 & 6.56 & 6.0 & 3.0 \\
$\frac{2}{6}$ & 16.40 & 5.47 & 6.0 & 2.4 \\
$\frac{3}{3}$ & 21.83 & 4.38 & 5.0 & 1.8 \\
$\frac{4}{4}$ & 27.33 & 3.28 & 5.8 & 2.3 \\
$\frac{5}{3}$ & 32.80 & 2.19 & 2.0 & 1.0 \\
$\frac{6}{2}$ & 38.30 & 1.09 & 1.5 & 1.2 \\
$\frac{7}{1}$ & & & &
\end{tabular}

A critical evaluation (21) of data published from 1906 through 1971 recommended:

$$
k=1.2 \cdot 10^{\circ} \cdot \exp (530 / \mathrm{T}) \quad \mathrm{cm}^{6} \mathrm{~mol}^{-2} \mathrm{~s}^{-1}
$$

at $22{ }^{\circ} \mathrm{C}=0.43 \cdot 10^{\circ} \quad 1^{2} \mathrm{~mol}^{-2} \min ^{-1} \quad$ for $-1 / 2 \frac{d[\mathrm{NO}]}{d t}=-\frac{d\left[\mathrm{O}_{2}\right]}{d t}=k[\mathrm{NO}]^{2}\left[\mathrm{O}_{2}\right]$

$$
=0.86 \cdot 10^{6} \quad 1^{2} \mathrm{~mol}^{-2} \mathrm{~min}^{-1} \quad \text { for }-\frac{d[\mathrm{NO}]}{d t}=k[\mathrm{NO}]^{2}\left[\mathrm{O}_{2}\right]
$$

(13) $\mathrm{k}=1.6 \cdot 10^{10} \mathrm{~cm}^{6} \mathrm{~mol}^{-2} \mathrm{~s}^{-1}=0.96 \cdot 10^{8} \mathrm{I}^{2} \mathrm{~mol}^{-2} \mathrm{~min}^{-1}$

(22) $k=1.44 \cdot 10^{4} \quad l^{2} \mathrm{~mol}^{-2} \mathrm{~s}^{-1}=0.86 \cdot 10^{6} \quad l^{2} \mathrm{~mol}^{2} \mathrm{~min}^{-1}$ 
of 15 - 20 lineal feet per minute as measured by anemometer. The deliveries varied by $3-4 \%$ regardless of draft but they were about $10 \%$ higher when draft was reduced. Fractional puff cut-offs might have increased deliveries but quenching cigarettes in the cassettes instead of removing them increased $\mathrm{CO}$ by only $3 \%, \mathrm{CO}_{2}$ by $2 \%$ and NO by $1 \%$.

\section{Nitric Oxide Oxidation}

Considering the average NO losses in Figure 3 to represent oxidation at the various NO-air ratios, velocity constants were calculated according to pseudo second order kinetics. The rate for the reaction $2 \mathrm{NO}+\mathrm{O}_{2} \rightarrow 2 \mathrm{NO}_{2}$ was defined by $-\frac{\mathrm{d}[\mathrm{NO}]}{\mathrm{dt}}=\mathrm{k} \cdot[\mathrm{NO}]^{2} \cdot\left[\mathrm{O}_{2}\right]$, where [NO] was the concentration of nitric oxide in mole per liter at time $t$ and $\left[\mathrm{O}_{2}\right]$ was the initial concentration of oxygen in mole per liter, assumed to be constant since $\left[\mathrm{O}_{2}\right] \gg[\mathrm{NO}]$. Thus $-\frac{\mathrm{d}[\mathrm{NO}]}{[\mathrm{NO}]^{2}}=\mathrm{k} \cdot\left[\mathrm{O}_{2}\right] \cdot \mathrm{dt}$ and on integrating, $\frac{1}{[\mathrm{NO}]}=\mathrm{k} \cdot\left[\mathrm{O}_{2}\right] \cdot \mathrm{t}+$ constant. At $\mathrm{t}=0$, the initial nitric oxide concentration was $[\mathrm{NO}]_{0}$, so $\frac{[\mathrm{NO}]_{0}-[\mathrm{NO}]}{[\mathrm{NO}]_{0}[\mathrm{NO}]}=\mathrm{k} \cdot\left[\mathrm{O}_{2}\right] \cdot \mathrm{t}$.

The velocity constants calculated as above (Table 2) were much higher than those found in a survey of literature values (21) indicating actual recoveries were extremely low. Utilizing $\mathrm{k}=0.86 \cdot 10^{8}$, calculations showed that recoveries of $99 \%$ were to be expected. If oxidation were considered in this system, about $10 \%$ of the NO in the $20 \mathrm{ml}$ line volume would be oxidized between puffs and succeeding puff levels would be reduced by this amount. However, line oxidation accounted for only $1 \%$ of the loss and an average loss of $4 \%$ remained unexplained.

\section{Low-Volume Filter Cassettes}

In the cigarette system, $10 \%$ oxidation of the $\mathrm{NO}$ in smoke left in the dead volume of the cassettes $(72 \mathrm{ml})$ and in the lines $(20 \mathrm{ml})$ between puffs would reduce recoveries by about $4 \%$ and reactions with smoke components would further reduce recovery. Therefore, low-volume cassettes (Figure 5) were fabricated with $3 \mathrm{ml}$ dead volume compared to the $9 \mathrm{ml}$ of a regular cassette. The low volume necessarily restricted flow such that draw resistance on the syringes (without a cigarette) was $4 \mathrm{~cm} \mathrm{H}_{2} \mathrm{O}$ compared to $1 \mathrm{~cm} \mathrm{H} \mathrm{H}_{2} \mathrm{O}$ for regular cassettes. However with a cigarette of $5-10 \mathrm{~cm} \mathrm{H}_{2} \mathrm{O}$ draw resistance, the difference in cassette resistance was negligible. Resistance to flow was mainly due to the reduced space in front of the Cambridge pad. The four holes were drilled in the outer perimeter in order to reduce resistance and to distribute particulates over the pad.

In 10 smokings of the same cigarette with each cassette, a comparison of Federal Trade Commission (FTC) condensate and nicotine deliveries showed both cassettes had essentially the same trapping efficiency and in 22 smokings, the $\mathrm{CO}$ and $\mathrm{CO}_{2}$ deliveries were similar as expected. The average NO delivery with the regular cassette, be-
Flgure 5. Low-volume Cambridge filter cassette with " $O$ " ring closure.
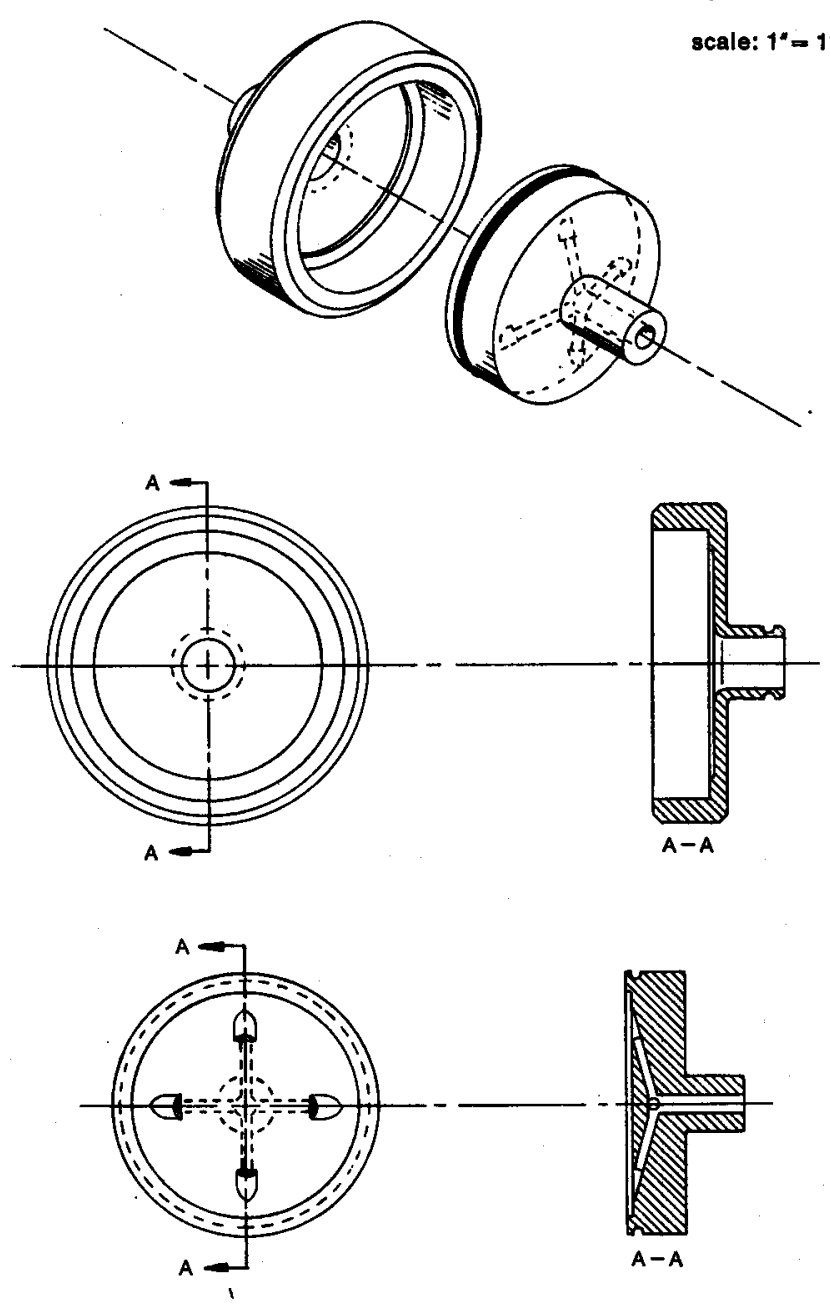

cause of the greater volume of NO to be oxidized, was four percent lower than delivery by the low-volume cassette. This difference was of about the same order as the relative error found for each type of cassette, indicating the dead volume of the regular cassette was not critical.

\section{Nitric Oxide Dependence on Blend Nitrate Nitrogen}

Although not extensively investigated, NO delivery of cigarettes was found to increase as blend nitrate nitrogen was increased. The best relation (Figure 6) was obtained utilizing average puff values rather than per cigarette deliveries because of the variation in puff numbers. The value at the origin was the delivery of a cellulose cigarette having $0.00 \%$ nitrate nitrogen and $0.00 \%$ total nitrogen in the shreds. Regression analysis of the data indicated at least $75 \%$ of the NO delivered by commercial cigarettes was derived from the nitrate nitrogen present in the tobacco.

\section{Interference in Non-dispersive Infrared (NDIR)} Analysis of NO

A deficiency in the NDIR analysis of NO in cigarette smoke was the analyzer response to other smoke constituents. Water tended to accumulate in the sample cell, 
Figure 6. Increase In nitric oxide deliverles with increased blend nitrate nitrogen.

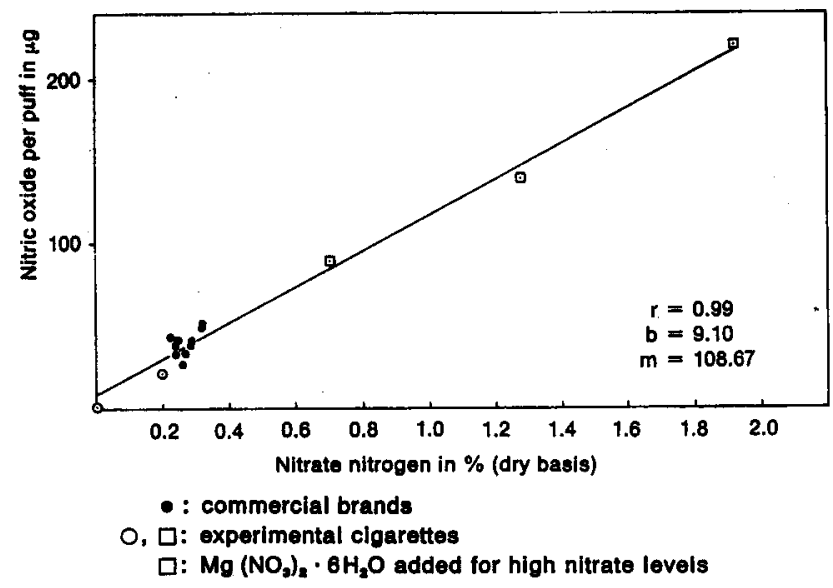

Flgure 7. Non-dlepersive Infrared (NDIR) response as nitric oxide to some smoke components.

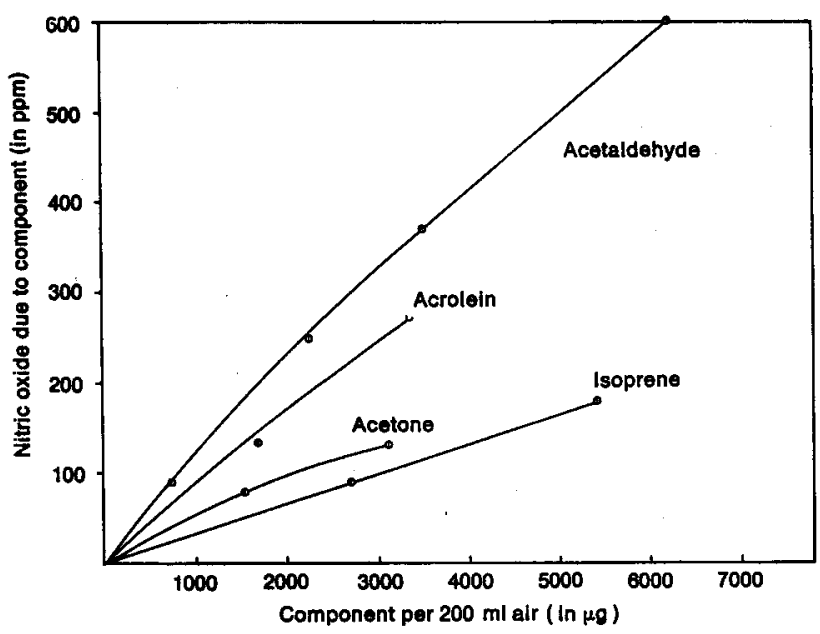

causing an increase in the meter zero and high $\mathrm{NO}$ values. This constituent was reduced to a negligible concentration by a capsule of $\mathrm{LiCl}$. Without $\mathrm{LiCl}$, analyzer zero with laboratory air was higher than with dry nitrogen. When passed through the $\mathrm{LiCl}$, laboratory air and dry nitrogen yielded the same zero. Another major interference was the aldehydes in smoke. The response of the analyzer to these major interfering species was determined as shown in Figure 7. Most were completely removed from smoke by a small capsule of silica gel, $6 \mathrm{~mm}$ inside diameter $\times 12 \mathrm{~cm}$ long, replaced before each set of cigarettes was smoked. Tests showed that little or no NO was removed by the silica gel as was also found by Foster and Daniels (23). Aldehydes removed by this silica gel after an NO smoking agreed with aldehydes delivery determined on the same cigarettes by routine aldehyde analyses (24).

\section{Automated Colorimetric Analyses}

The nitric oxide oxidation velocity constant of $0.86 \cdot 10^{\circ}$ indicated that in wet analyses of NO, such as the Saltzman procedure, at least 3 hours exposure would be necessary for complete oxidation. If the coloring reagents were present initially, they could decompose in long periods of exposure to smoke and produce erroneous results. Therefore, smoke and standard gases were analyzed by a modified AutoAnalyzer method of Collins et al. (14) in which the coloring reagents were added during the analyses so that no decomposition occurred. In exploratory evaluations of this method, adapted to measure both nitrate $\left(\mathrm{NO}_{3}{ }^{-}\right)$and nitrite $\left(\mathrm{NO}_{2}-\right)$, standard gases were injected into evacuated 1-liter flasks and absorbed in solution. Analyses showed that $\mathrm{NO}_{2}$ and $\mathrm{O}_{2}$ produced $\mathrm{NO}_{2}^{-}$and $\mathrm{NO}_{3}-$, whereas $\mathrm{NO}$ and just enough $\mathrm{O}_{2}$ to react completely to $\mathrm{N}_{2} \mathrm{O}_{3}$ produced essentially $\mathrm{NO}_{2}-$ only. In the analysis of smoke, various ratios of $\mathrm{NO}_{2}-$ and $\mathrm{NO}_{3}-$ were found indicating both $\mathrm{NO}_{2}$ and $\mathrm{N}_{2} \mathrm{O}_{3}$ were absorbing. Therefore, the AutoAnalyzer was adapted to reduce $\mathrm{NO}_{5}-$ to $\mathrm{NO}_{2}-$ and all the oxides were determined as $\mathrm{NO}_{2}-$. In the course of these studies, aldehydes were found to interfere in the color forming phase of the analyses so they were destroyed by a bromine water treatment, excess bromine reacting with the hydrazine before the nitrate reduction. Dr. Collins has kindly consented to a prepublication of the reagents (Table 3 ) and a schematic of the AutoAnalyzer manifold (Figure 8).

Individual cigarettes were smoked on a single-port syringe smoker, valved to exhaust each puff into an evacuated one-liter flask containing $100 \mathrm{ml} 0.1 \mathrm{~N} \mathrm{NaOH}$.

\section{Table 3. AutoAnalyzer reagents.}

Use reagent grade chemicals and distilled water to prepare all solutions.

1. $\mathrm{NaOH}, 0.1 \mathrm{~N}$. Dissolve and dilute $4.0 \mathrm{~g}$ of $\mathrm{NaOH}$ to $1000 \mathrm{ml}$ with $\mathrm{H}_{2} \mathrm{O}$.

2. $\mathrm{NaOH}, 0.425 \mathrm{~N}$. Dissolve and dilute $17 \mathrm{~g}$ of $\mathrm{NaOH}$ to $1000 \mathrm{ml}$ with $\mathrm{H}_{2} \mathrm{O}$.

3. Bromine water. Prepare saturated bromine water by adding $3 \mathrm{ml}$ of bromine to $100 \mathrm{ml}$ of $\mathrm{H}_{2} \mathrm{O}$ and allowing the mixture to stand in a glass-stoppered bottle until equilibrated, at least several hours. Prepare the dilute bromine water to be used with the AutoAnalyzer freshly each day by diluting $2 \mathrm{ml}$ of saturated bromine water to $100 \mathrm{ml}$ with water.

4. CuSO solution. Dissolve and dilute $25 \mathrm{mg}_{4}$ of $\mathrm{CuSO}_{4}$. $5 \mathrm{H}_{2} \mathrm{O}$ to $1000 \mathrm{ml}$ with $\mathrm{H}_{2} \mathrm{O}$.

5. Hydrazine sulfate solution. Dissolve and dilute $0.69 \mathrm{~g}$ of $\mathrm{N}_{2} \mathrm{H}_{4} \cdot \mathrm{H}_{2} \mathrm{SO}_{4}$ to $1000 \mathrm{ml}$ with $\mathrm{H}_{2} \mathrm{O}$. This solution is stable for one month.

6. Aqueous. acetone solution. Dilute $100 \mathrm{ml}$ of acetone to $1000 \mathrm{ml}$ with water.

7. Color reagent. In $750 \mathrm{ml}$ of water, dissolve $100 \mathrm{ml}$ of $85 \% \mathrm{H}_{3} \mathrm{PO}_{4}, 40 \mathrm{~g}$ of sulfanilamide and $2.0 \mathrm{~g}$ of $\mathrm{N}-(1-$ naphthyl)ethylenediamine dihydrochloride. Dilute to $1000 \mathrm{ml}$. The solution should be kept in a cool, dark place and is usable for 4 weeks.

8. Standard $\mathrm{NO}_{3}^{-}-\mathrm{N}$ solutions. Prepare a $100 \mathrm{ppm} \mathrm{NO}_{3}^{-}-\mathrm{N}$ standard by dissolving $0.3608 \mathrm{~g}$ of primary standard $\mathrm{KNO}_{3}$ in water and diluting to $500 \mathrm{ml}$. Dilute $50 \mathrm{ml}$ of this solution to $500 \mathrm{ml}$ to obtain a $10 \mathrm{ppm} \mathrm{\textrm {NO } _ { 3 }}-{ }_{-}^{-} \mathrm{N}$ standard. Prepare working standards by diluting 2, 5, 10, 15 and $20 \mathrm{ml}$ of $10 \mathrm{ppm} \mathrm{NO}_{3}{ }^{-}-\mathrm{N}$ each to $100 \mathrm{ml}$; these standards are $0.2,0.5,1.0,1.5$ and $2.0 \mathrm{ppm}$ in $\mathrm{NO}_{3}{ }^{-} \mathrm{N}$.

9. $\mathrm{HCl}, 1 \mathrm{~N}$. Dilute $83 \mathrm{ml}$ of conc. $\mathrm{HCl}$ to 1 liter with $\mathrm{H}_{2} \mathrm{O}$. 


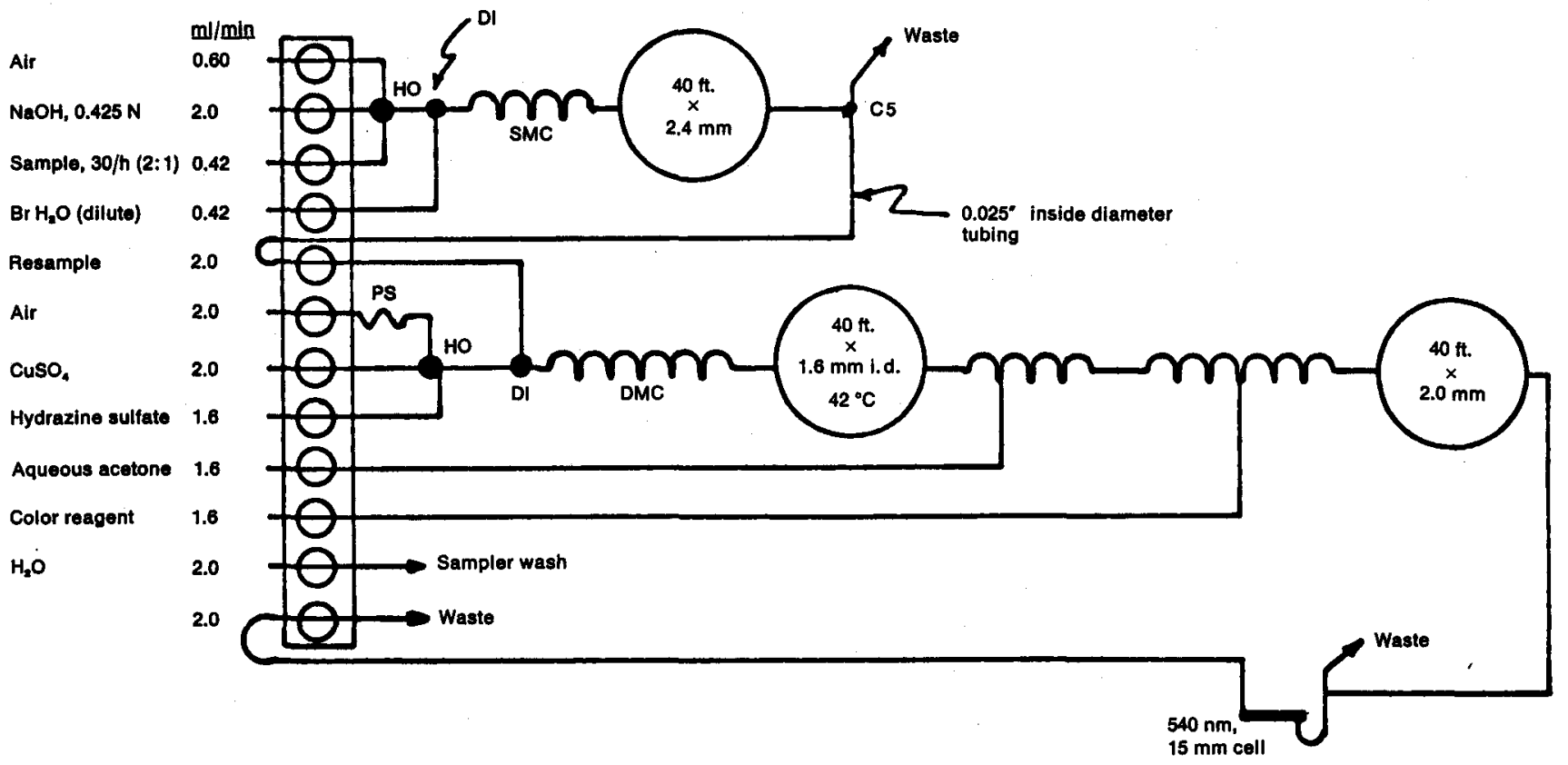

After venting the flask to atmosphere, samples of absorbent were withdrawn periodically for AutoAnalyzer analysis and the extent of oxidation was calculated. The oxidation of NO in smoke from commercial cigarettes having perforated (low yield) and non-perforated (high yield) filters is shown in Figure 9. Standard gases (2030 ppm NO and $1050 \mathrm{ppm} \mathrm{NO}$ in $\mathrm{N}_{2}$ ) were also charged to flasks in amounts nearly equivalent to the cigarette delivery and the extent of oxidation was determined as in the smoke analyses. As seen, the disappearance rates were similar, and considerably longer than one hour was required for complete NO oxidation. These results account for inconsistent values for high and low-yield cigarettes by wet methods where oxidation periods of only 30 minutes are allowed before analysis. The NO from a high-yield cigarette would be about $73 \%$ oxidized while for a low-yield cigarette, oxidation would be only about $36 \%$ after 30 minutes.

The oxidation of standard gases was further examined by non-dispersive infrared (NDIR) spectroscopy by isolating the sample cell after admitting a similar standard gas-air mixture and recording NO disappearance. Figure 10 shows a comparison of NO disappearance rates by NDIR and

Flgure 9. AutoAnalyzer analyses of nitric oxide oxidation In smoke and In standard gases.

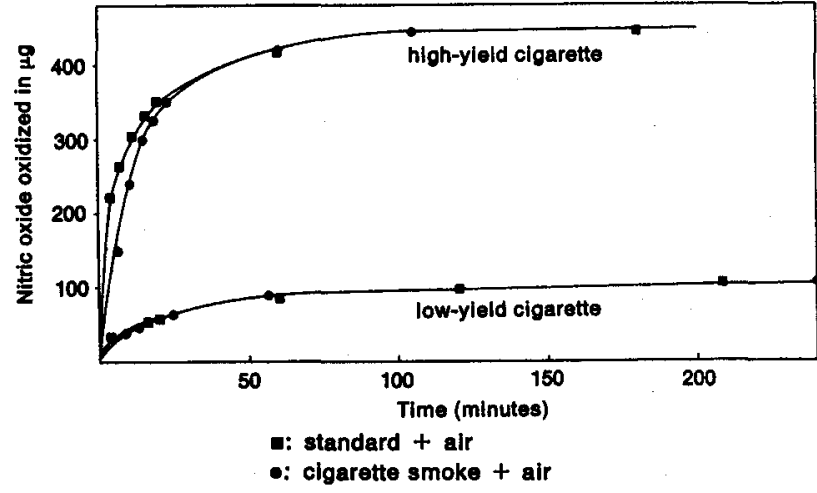

AutoAnalyzer. The standard-air mixture made up in a one-liter syringe would parallel flask mixing which could reflect imperfect initial mixing so a flow mix of a stream of standard and a stream of air was also examined. Since the flow and syringe oxidations by NDIR were similar, initial mixing in the flasks and syringe were probably complete. The NDIR oxidation was possibly slower than flask oxidation because the NDIR cell is thermostated to $50^{\circ} \mathrm{C}$ and $\mathrm{NO}$ oxidation rate decreases with increased temperature (20). The AutoAnalyzer procedure also detects $\mathrm{NO}_{2}$ that could form in the syringe and infrared cell before the analyzer stabilized for reading.

With cigarettes, agreement between NDIR and AutoAnalyzer results were obtained by analyzing the same gas phase smoke from the eight-port smoking machine. A $35 \mathrm{ml}$ aliquot of each puff $(280 \mathrm{ml} \triangleq 8$ ports) was taken through a "tee" before the NDIR analyzers and was added to an evacuated flask. AutoAnalyzer analyses after 17 hours air oxidation are compared to the NDIR analyses for several commercial brands and experimental cigarettes in Table 4. The consistently lower NDIR analyses can be attributed to the 15 -second interval between

Figure 10. AutoAnalyzer and non-dleperelve infrared (NDIR) analyses of nltric oxIde in standard gases.

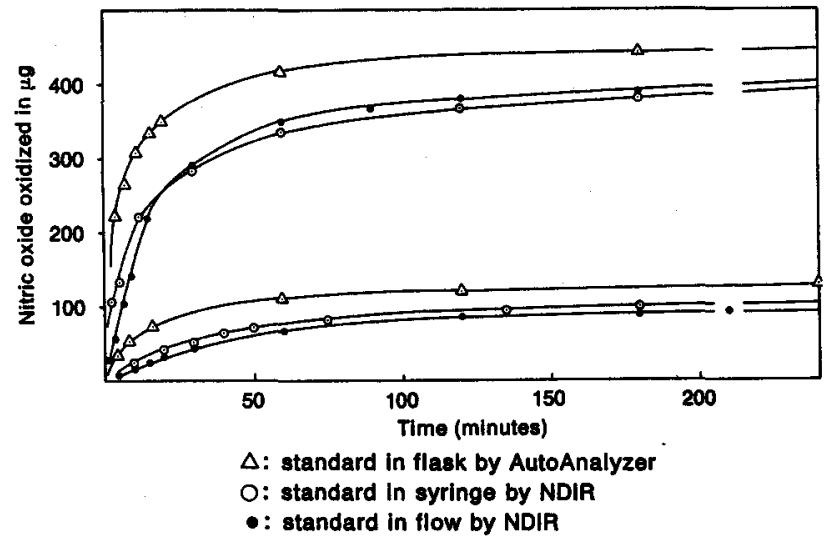


Table 4. Nitric oxide dellveries of clgarettes by AutoAnalyzer and non-dlepersive Infrared (NDIR) analyses of the same smoke.

\begin{tabular}{lcc}
\hline Cigarette & $\begin{array}{c}\mu g \text { NO/cig. } \\
\text { (AutoAnalyzer) }\end{array}$ & $\begin{array}{c}\mu g \text { NO/cig. } \\
\text { (NDIR) }\end{array}$ \\
\hline A Non-filter & 229,257 & 210,249 \\
B Non-perforated filter & 283,277 & 256,270 \\
C Non-perforated filter & 255,258 & 250,255 \\
D Perforated filter & 191,205 & 172,200 \\
E Perforated filter & 107,119 & 91,119 \\
F Perforated filter & 77,82 & 63,66 \\
\hline
\end{tabular}

* $35 \mathrm{ml}$ allquot of each 8-port puff taken while $245 \mathrm{ml}$ passed into NOIR analyzer. Aliquots added to evacuated 1-liter flask.

the puff and the stabilization of the analyzer for reading wherein the $\mathrm{NO}$ oxidized would be detected as $\mathrm{NO}_{2}$ by the AutoAnalyzer and to the interval between puffs. In a study of simultaneous colorimetric, NDIR and chemiluminescence analyses of similar cigarette smoke and standard gas mixtures (in preparation), results were in the ratio of $1.1: 1.0: 0.09$.

\section{SUMMARY}

Nitric oxide in cigarette smoke was conveniently determined by non-dispersive infrared analysis (NDIR). Recoveries of $95 \%$ were obtained with standard gas-air mixtures but recoveries from smoke increased from $87 \%$ for high-yield to $91 \%$ for low-yield cigarettes. Relative error was about $4 \%$. A reduction in the dead volume of Cambridge filter cassettes, to reduce the amount of NO reacted between puffs, increased NO deliveries of cigarettes by $4 \%$. Deliveries of NO were estimated to average $4 \%$ lower due to oxidation, but reaction with other smoke components reduced them further depending upon concentrations. The NO deliveries of cigarettes increased as blend nitrate increased and as the flow of air around cigarettes decreased. Nitric oxide in smoke and in standard gas-air mixtures, determined by non-dispersive infrared (NDIR) spectroscopy, was substantiated by an automated colorimetric analysis. Interfering smoke species were determined and circumvented in both methods.

\section{ZUSAMMENFASSUNG}

Der Stickstoffmonoxidgehalt des Cigarettenrauches wurde auf einfache Weise durch nichtdispersive Infrarotanalyse (NDIR) bestimmt. Während die Wiederauffindungsrate bei Standardgemischen von Gas und Luft 95\% betrug, belief sie sich im Rauch von Cigaretten mit hoher Ausbeute an Rauchinhaltsstoffen auf $87 \%$ und erhöhte sich im Rauch von Cigaretten mit niedriger Ausbeute auf 91\%. Die relative Fehlerquote lag bei etwa 4\%. Eine Verminderung des Totvolumens der Cambridgefilter-Kassetten mit dem Ziel, möglichst wenig NO zwischen den Zügen zur Reaktion kommen zu lassen, ließ die Ausbeuten an NO um 4\% ansteigen. Es ist anzunehmen, daß die NOAusbeuten durch Oxidation im Durchschnitt um 4\% niedriger liegen und sich durch Reaktion mit anderen Rauchbestandteilen je nach deren Konzentration weiter verringern. Die Ausbeute des Cigarettenrauches an Stick- oxid nahm mit der Erhöhung des Nitratgehaltes der Tabakmischung und mit der Verminderung des die Cigarette umgebenden Luftstromes zu. Die durch nichtdispersive Infrarotanalyse erhaltenen. Werte für Stickstoffmonoxid im Rauch und in Standardgemischen von Gas und Luft konnten durch automatische Kolorimetrie bestätigt werden. Der Einfluß von Störsubstanzen im Rauch wurde bestimmt und bei Anwendung beider Verfahren ausgeschaltet.

\section{RESUME}

La concentration d'oxide nitrique dans la fumée de cigarette a été déterminée d'une manière simple par analyse infrarouge non dispersive (NDIR). On a obtenu des taux de récupération de $95 \%$ dans des mélanges standard gaz/ air, mais dans la fumée de cigarette, ce taux a passé à $87 \%$ pour les cigarettes à rendement élevé et à $91 \%$ pour les cigarettes aे faible rendement. La marge d'erreur relative est d'environ $4 \%$. Une diminution du volume mort des cassettes à filtre Cambridge, destinée à diminuer au maximum la réaction du NO entre les bouffées, a entraîné une augmentation de $4 \%$ du NO dans la fumée. On peut admettre que les rendements en NO sont réduits en moyenne de $4 \%$ par oxidation et qu'ils diminuent encore par réaction avec d'autres constituants de la fumée, selon leur concentration. Le rendement en oxide nitrique de la fumée de cigarette s'accroît avec l'augmentation de la teneur en nitrate du mélange de tabac et avec la diminution du flux d'air autour de la cigarette. Les valeurs obtenues par l'analyse infrarouge non dispersive de l'oxide nitrique dans la fumée de cigarette et dans les mélanges standard de gaz et d'air ont été confirmées par colorimétrie automatique. Des composants de la fumée interférant avec les mesures ont été déterminés et éliminés dans les deux méthodes.

\section{REFERENCES}

1. Saltzman, B. E.: Analytical Chemistry 26 (1954) 1949-1955.

2. Ibid.: 32 (1960) 135-136.

3. Norman, V., C. H. Keith: Nature 205 (1965) 915916.

4. Fischer, G. E., and D. E. Becknell: Anal. Chem. 44 (1972) 863-866.

5. Norwitz, G.: Analyst 91 (1966) 553-558.

6. Laby, R. H., and T. C. Morton: Nature 210 (1966) 298-299.

7. Scherbak, M. P., and T. A. Smith: Analyst 95 (1970) 964-968.

8. Urbanic, J. E., and R. F. Shutt: Paper presented at 23rd Tobacco Chemists' Research Conference, Philadelphia, Pa., October 22-24, 1969.

9. Williams, T. B., and C. W. Belk, II: Paper presented at 27th 'Tobacco Chemists' Research Conference, Winston-Salem, N. C., October 3-5, 1973.

10. Neurath, G., and M. Dünger: IARC (International Agency for Research on Cancer) Sci. Publ. No. 3, 1972, 134-136. 
11. Cumming, E. M.: Beitr. Tabakforsch. 8 (1975) 153157.

12. Klimisch, J. H., and E. Kirchheim: Z. Lebensm.Untersuch. u. -forsch. 163 (1977) 48-52.

13. Sloan, C. H., J. E. Kiefer: Tobacco Science 13 (1969) 180-182.

14. Collins, P. F., J. F. Williams, B. H. Gerritsen: Tobacco Science 11 (1967) 75-78.

15. Williams, T. B., C. W. Belk, II: Beitr. Tabakforsch. 6 (1972) 210-215.

16. Wiley, R, M., and J. A. Ferri: Tobacco Science $\mathbf{1 1}$ (1967) 140-143.

17. Collins, P. F., J. F. Williams: Beitr. Tabakforsch. 7 (1973) 67-72.

18. Baker, R. R., R. A. Crellin: Beitr. Tabakforsch. 9 (1977) 131-140.

19. Siggia, S.: Continuous analysis of dhemical process systems; John Wiley and Sons, Inc., New York, N.Y., pp. 88, 1959.

20. Neurath, G. B., M. Dünger, F. G. Pein: IARC (International Agency for Research on Cancer) Scientific Publication No. 14, 1976, 215-225.

21. Baulch, D. L., D. N. Drysdale, D. G. Horne, A. C. Lloyd: Evaluated kinetic data for high temperature reactions, Volume 2: Homogeneous gas phase re- actions of the $\mathrm{H}_{2}-\mathrm{N}_{2}-\mathrm{O}_{2}$ system; Butterworth and Co., Ltd., London, p. 285-300, 1973.

22. Cooper, P. J., R. B. Hege: The oxidation of NO to $\mathrm{NO}_{2}$ in cigarette smoke; Paper presented at 32nd Tobacco Chemists' Research Conference, Montreal, Canada, October 30-Nov. 1, 1979.

23. Foster, E. G., F. Danields: Industrial and Engineering Chemistry 43 (1951) 986-992.

24. Collins, P. F., N. M. Sarji, W. W. Lawrence, J. F. Williams: Tobacco Science 14 (1970) 182-186.

\section{Adknowledgements}

The contributions of the following are gratefully adknowledged: C. W. Belk, II, and N. E. Magurean (data and procedural development), C. J. Walker and R. P. Kirby (smoking machine development), Dr. P. F. Collins (AutoAnalyzer analyses and helpful discussions).

Author's address:

Liggett \& Myers.Tobacco Co., Inc.,

Research Center,

West Main \& Fuller Streets,

Durham, N.C., 27702,

U.S.A. 